\title{
A method to impregnate wet soil samples, producing high-quality thin sections
}

\author{
R. Miedema, Th. Pape and G. J. van de Waal \\ Agricultural University, Department of Soil Science and Geology, \\ Wageningen, the Netherlands
}

Accepted: 14 December 1973

\section{Summary}

Mineral soils with different moisture contents and variable in texture have been impregnated successfully by the described method. The water present in the soil sample is replaced by aceton. The resulting aceton-saturated sample is impregnated according to the method of FitzPatrick (1970). Minimal shrinking occurs and the produced thin sections are of a high quality.

With this method it should be possible to correlate thin section data to physical data obtained from undisturbed material. Micromorphologically we may get a better understanding of the plasmic fabrics.

\section{Introduction}

Recently we changed our impregnation method to the one described by FitzPatrick (1970) using aceton as thinner of the polyester resin Synolith 544 we use. This method gives very good results, presumably due to a lower viscosity of the impregnation mixture, with soils who formerly gave troubles with impregnation. Among these soils were unripe subsoils, very heavy clay soils and tropical soils with a very high iron content.

Since several years workers in micromorphology have been experimenting to find suitable methods for the impregnation of wet soil samples. Mitchell (1956), Tourtelot (1961) and Greene-Kelly (1970) used polyethylene glycol (Carbowax 6000). Freezedrying, followed by one of the usual impregnation methods, is applied by Werner (1966), Blevins (1968), von Stephan (1969), Kubiena (1971) and others. Lund (1965) already describes a replacing technique and Singh (1969) replaces the water in the samples by aceton and the aceton by monostyrene before the impregnation with a mixture of epoxy resin and monostyrene.

The method described here is based on the mixability of aceton with both water and impregnation resin. Replacement of the aceton by monostyrene as in the method of Singh is not needed in our method.

\section{Material}

Preliminary trials with a clayey peat sample and a clay sample were encouraging. Further experiments were carried out with samples from different soils. Apart from 
R. MIEDEMA, TH. PAPE AND G. J. VAN DE WAAL

Table 1. Some characteristics of the soils used.

\begin{tabular}{|c|c|c|c|c|c|c|c|c|c|}
\hline \multirow[t]{2}{*}{ Profile } & \multirow{2}{*}{$\begin{array}{l}\text { Depth } \\
\mathrm{cm}\end{array}$} & \multirow[t]{2}{*}{$<^{2} \mu \mathrm{m}$} & \multirow{2}{*}{$\begin{array}{l}2-50 \mu \mathrm{m} \\
\%\end{array}$} & \multirow{2}{*}{$\underset{\%}{>50 \mu \mathrm{m}}$} & \multirow{2}{*}{$\frac{\text { Moisture }}{\%(v / v)}$} & content & \multirow{2}{*}{$\begin{array}{l}\text { Bulk } \\
\text { density } \\
\mathrm{g} / \mathrm{cm}^{3}\end{array}$} & \multirow{2}{*}{$\begin{array}{l}\text { Pore } \\
\text { space } \\
\%(v / v)\end{array}$} & \multirow[t]{2}{*}{ n value } \\
\hline & & & & & & $\%(w / w)$ & & & \\
\hline Mijdrecht & $80-85$ & 51.4 & 49.3 & 0.3 & 73.9 & 123.6 & 0.60 & 76.8 & 1.8 \\
\hline Haarlemmermeer & $73-78$ & 51.2 & 45.7 & 3.1 & 67.4 & 91.3 & 0.74 & 72.0 & 1.4 \\
\hline Nuth & $0-22$ & 11.5 & 81.6 & 6.9 & 34.6 & 21.5 & 1.58 & 40 & \\
\hline Nuth & $31-46$ & 16.0 & 73.7 & 10.3 & 18.0 & 31.2 & 1.73 & 35 & \\
\hline Randwijk & $0-25$ & 36.3 & 56.1 & 7.7 & 30.0 & 42.0 & 1.40 & 48 & \\
\hline
\end{tabular}

the samples to be impregnated we took core samples of the same layer to determine some characteristics of the soils used. These can be found in Table 1. It can be seen that the investigated profiles have large differences in clay and moisture content. Mijdrecht has been selected because planar voids in the permanently reduced zone do not exist. Mijdrecht and Haarlemmermeer are unripe to half-ripe alluvial soils with a very low bulk density and very high pore space. They have a very high clay and moisture content. Nuth is a colluvial loess profile and Randwijk is a heavy levee or light basin clay soil. They have moisture contents around field capacity. The illitic clay contents vary from 10 to $50 \%$. The moisture contents on weight basis show differences from 21 to $123 \%$.

\section{Method}

Round and rectangular samples, $3 \mathrm{~cm}$ thick, are placed in a stainless steel impregnation box, with some space between the bottom and the samples. Aceton is added from the bottom to the top, enabling the aceton to reach the top of the sample by capillary rise. Aceton is added until the sample is submerged. To prevent evaporation of the aceton, aluminium foil or a tightly fitting lid are used to cover the impregnation box. About once a week the water/aceton mixture is syphoned off and immediately replaced by pure aceton. The water content is measured by weighing a known volume of the mixture and calculating the water content by means of the specific weights. This replacement is repeated until no water is detected in the mixture syphoned off. The aceton-saturated sample, including the sample box, is carefully impregnated from the bottom to the top with Synolith/aceton mixture. The composition of this mixture is for a total volume of about 3 1: $1500 \mathrm{~cm}^{3}$ Synolith 544:, $1500 \mathrm{~cm}^{3}$ aceton', $1.5 \mathrm{~cm}^{3} 1 \%$ Cobaltoctoate NL $49^{3}$ and $3 \mathrm{~cm}^{3}$ Cyclonox LTM 503. Thorough stirring is necessary after each addition. Care should be taken not to add Cobaltoctoate and Cyclonox together because of explosive reaction. The amounts of Synolith, aceton, Cobaltoctoate and Cyclonox depend on working temperature and amount prepared.

The samples thus impregnated are evacuated twice for 2 minutes and then kept covered for 3 to 4 days to avoid too rapid evaporation of the aceton. If the impregnation liquid is below the top of the samples, undiluted Synolith is added until the

I Supplied by Frencken, Weert, the Netherlands.

2 Supplied by Brocades, Arnhem, the Netherlands.

$\checkmark$ Supplied by Noury and Van der Lande, Deventer, the Netherlands. 
samples are submerged again. The samples are then left uncovered in the fume cupboard. After 3-4 days vacuum is applied until the point where the liquid almost boils. This is repeated twice at the same intervals. The underpressure was about 100, 90 and $60 \mathrm{~mm} \mathrm{Hg}$ for the successive steps.

Hardening takes 5 to 6 weeks. The samples are put in the oven for 3 days at $40^{\circ}$ and for 3 hours at $70^{\circ} \mathrm{C}$, and are left in the oven to cool down. They are ready now to be removed from the sample boxes, cut and ground. These techniques do not need further explication.

The described method is rather time-consuming, and is not meant to replace other methods used on a routine basis. High ratios of aceton compared to the amount of moisture in the sample speed up the process of replacing the water by aceton.

\section{Results and discussion}

Samples of the above-mentioned soils were well-impregnated, resulting in thin sections of very good quality. Some shrinking did occur (about $5 \%$ ), but this may partially or fully be due to the inevitable shrinking during hardening of the resin used.

The blocks of Mijdrecht and to a lesser extent also those of Haarlemmermeer cracked severely, after thin section preparation, when exposed to air drying. This could mean that still some water is left in the sample, although it did not interfere with the impregnation, sawing and grinding. The samples of Nuth and Randwijk did not show this cracking of the blocks. If after a while cracking of the block occurs it is impossible to make a duplicate thin section of it. This problem can be easily overcome by making more thin sections of the block as quick as possible. The thin sections do not show any artificial cracking at all.

\section{References}

Blevins, R. L., G. M. Aubertin \& N. Holowaychuk, 1968, A technique for obtaining undisturbed soil samples by freezing in situ. Proc. Soil Sci. Soc. Am. 32: 741.

Bouma, A. H., 1969. Methods for the study of sedimentary structures. Wiley-Interscience, New York, p. 84.

FitzPatrick, E. A., 1970. A technique for the preparation of large thin sections of soils and unconsolidated materials. In: Micromorphological techniques and applications. Harpenden, Technical Monograph 2: 3.

Greene-Kelly, R. \& S. Chapman, 1970. The preparation of thin sections of soils using polyethylene glycols. In: Micromorphological techniques and applications. Harpenden, Technical Monograph 2: 15 .

Jongerius, A. \& G. Heintzberger, 1963. The preparation of mammoth-sized thin section. Soil Surv. Pap. 1. Soil Survey Institute, Wageningen.

Kubiena, W. L. \& E. Geyger, 1971. Methods used in micromorphological studies and in micromorphometric soil studies. In: Ecological studies, analysis and synthesis, Vol. 2: 169.

Lund, Z. F. \& H. O. Beals, 1965. A technique for making thin sections of soil with roots in place. Proc. Soil Sci. Soc. Am. 29: 633.

Mitchell, J. K., 1956. The fabric of naturel clays and its relation to engineering properties. Proc. Highiw. Res. 35: 693.

Singh, R. B., 1969. A versatile method for treatment of clay soils for thin-section fabric studies. J. Soil Sci. $20(2): 270$.

Stephan, S. von, 1969. Gefriertrocknung und andere bei der Herstellung von Bodendünnschliffen benutzbare Trocknungsverfahren. Z. PflErnähr. Dïng. Bodenk, 123 (2): 131.

Tourtelot, H. A., 1961. Thin sections of clay and shale. J. Sedim. Petrol. 31: 131.

Werner, F., 1966. Herstellung von ungestörte Dünnschliffen aus wassergesättigten, pelitischen Lockersedimenten mittels Gefriertrocknung. Meyiana 16: 107. 